\title{
The Music Collection of the Brno St. James Regenschori Matthaeus Rusmann and its Inventory from 1763
}

Michaela Ratolístková / 362500@mail.muni.cz

Department of Musicology, Faculty of Arts, Masaryk University, Brno, CZ

Jana Spáčilová / jana.spacilova@upol.cz

Department of Musicology, Faculty of Arts, Palacký University, Olomouc, CZ

\begin{abstract}
The study deals with the music inventory of the St. James parish church in Brno from 1763 in relation to the music collection of regenschori Matthaeus Rusmann. It includes a detailed inventory description and analysis of its content. Attention is also paid to comparing the inventory with the current state of the collection and the identification of recorded music sheets.
\end{abstract}

\section{Keywords}

St. James parish church in Brno, music collection, choirmaster Matthaeus Rusmann, inventory

The article came into being as part of the project "Hudební inventáře raného novověku v českých zemích" supported by the Grantová agentura České republiky (project no. GA16-17615S). 
The great importance of the music collection of the St. James parish church in Brno has already been mentioned in existing literature several times, but none of the works dealt with the collection in its entirety. The reason is the extent of the collection, as well as its time span ranging from the end of the $17^{\text {th }}$ century up until the beginning of the $20^{\text {th }}$ century. The collection includes more than 2,000 music sheets and is currently housed in the Department of the History of Music at the Moravian Museum. ${ }^{1}$ Its division into an older and a newer part reflects the fact that it was transferred into the Moravian Museum in two phases with a time lag of almost fifty years, as well as the content of the collection itself: the older part contains music sheets prevalently from the $17^{\text {th }}$ and $18^{\text {th }}$ centuries, while the newer part contains more recent ones. ${ }^{2}$ This division is, however, not strictly accurate: both parts of the collection include music sheets beyond the above defined ranges. ${ }^{3}$

The present research aims to investigate in greater detail the part of the collection from its oldest works up until the beginning of the $19^{\text {th }}$ century, as well as the music-related operations of the St. James' choir. ${ }^{4}$ The division of the research focus corresponds to the division of music sheets based on their previous owners and their activity in the position of St. James' regenschori. The amassing of the older part of the collection took place in about three phases and was represented by the following choirmasters:

1) Matthias Franz Altmann (1715-1718) with his son Ferdinand Franz Altmann (17181721),

2) Matthaeus Rusmann (1721-1762),

3) Peregrin Gravani (1763-1815).

Research work on the collection resulted in the selection of approximately 900 relevant music sheets belonging to one of the three choirmasters. ${ }^{5}$ The next task was to determine which of the three men was the owner of the particular works. The task proved difficult, as the individual parts of the collection are closely intertwined with regard to the repertory. The main objective of the research, the outcomes of which are presented

1 Other sources concerning the music-related operations of the St. James' church are deposited in the Brno City Archives. These include, among other items, valuable manuscripts of a Dutch polyphony from the $16^{\text {th }}$ century. See HORYNA, Martin - MAŇAS, Vladimír. Two Manuscripts of Polyphonic Music in Brno from the Mid-Sixteenth Century. Early Music 40, 2012, Nr. 4, p. 553-575. See also MANAS, Vladimír. The choir lofts in the church of St. James in Brno (between the late 15th and the 19th centuries). Musicologica Brunensia 51, 2016, Nr. 1, p. 103-111.

2 The older part: STRAKOVÁ, Theodora - SEHNAL, Jiří - PŘIBÁŇOVÁ, Svatava. Prưvodce po archívnich fondech Ústavu dějin hudby Moravského musea v Brně, Brno 1971, p. 25-27. The newer part: KYAS, Vojtěch. Prưvodce po archivnich fondech II. Oddèleni dějin hudby Moravského zemského muzea (Přriruistky za léta 1971-2001 a doplňky), Brno 2007, p. 11-12.

3 The older part of the collection includes the following call marks: A 1517 - A 2375, A 3927 - A 4301 ; the newer part includes the following ones: A 46574 - A 46723, A 46853 - A 47260, A 47635 - 47934 , A 50521 A 50527.

4 The PhD research team of the Department of Musicology, the Faculty of Arts, Masaryk University, consists of Michaela Ratolístková (supervisor Jana Perutková) and Helena Kramářová (supervisor Vladimír Maňas). Staffing in the period after the Battle of White Mountain is documented in detail in a study by STUDENIČOVÁ, Hana. Kantoři, varhaníci a věžní u sv. Jakuba v Brně v 16. století. In Brno v minulosti a dnes. Př́spěvky $k$ dějinám a výstavbě Brna, Archiv města Brna, 2017, vol. 30, December, p. 127-145.

5 The music sheets from the $19^{\text {th }}$ cenutry acquired by choirmaster Leopold Streit specifically are currently beyond the scope of focus of our research. 
in this study, was to identify the music sheets originally owned by regenschori Rusmann and compare them to the St. James' inventory of 1763.

\section{Matthaeus Rusmann and His Importance for the Development of the St. James' Collection}

The St. James regenschori Matthaeus Rusmann (Ruesmon) was undoubtedly one of the most prominent personalities involved in the music life in Brno from the 1720s to the 1760s. A key aspect of his life was his connection to Vienna and a personal acquaintance with composers of the imperial court. Prior to his arrival in Brno, for five years he worked for St. Michael's church in Vienna, which served as the parish church of the imperial court. ${ }^{6}$ Rusmann was employed in St. Michael's choir as a choralist and an assistant to the choirmaster with an annual salary of $15 \mathrm{fl}$ as of $1716 .^{7}$ The choirmaster at the time was Johann Michael Spazierer (Procházka) from Dolní Kounice, who surrounded himself with Moravian musicians and initiated the acquisition of a new organ for St. Michael's, constructed in 1714 by the Brno organ builder Johann David Sieber. The same church hosted a fraternity of court musicians Confraternità della Divina Grazia. According to accounting records from 1721, Rusmann worked directly for this fellowship and undoubtedly had a personal acquaintance with members of the imperial ensemble. ${ }^{8}$

As early as his application for the post of regenschori from 1721, Rusmann claimed he was able to acquire entirely new compositions "in the Viennese style" for the St. James' choir directly from St. Michael's or from the local composers he knew personally. ${ }^{9}$ In his request for a salary raise from 12 October 1723, Rusmann highlighted the great music pieces he obtained through his friendship with Viennese musicians and especially those at the court. He managed, with great effort, to copy 2,000 sheets ("2 tausend bögen") for St. James'. ${ }^{10}$ The existing literature incorrectly states 2,000 music pieces; with ten to

6 In his application for the position of St. James' regenschori from 12 September 1721, he signed himself as "Matthaeus Ruesmon, Vice Regens Chori und Bassista in der Kays.-Hoff-Pfarrkirche bey St. Michael in Wien". Archiv města Brna (AMB) [Brno City Archives], fond 1/9 Stará registratura, inv. no. 18, sign. C 43, cart. 36, Členové kůru sv. Jakuba 1678-1766 [Members of St. James choir 1678-1766], folder 70.

7 SCHÜTZ, Karel. Musikpflege an St. Michael in Wien. Wien 1980, p. 132, 143.

8 SCHÜTZ, op. cit., p. 67-68.

9 " [...] ich auch vor andern juxta modum Viennensem solche nach allen Contento zu Prestiren mich getraue, auch zu folge diesen in all erforderenten fall neueste Musicalien nicht nur allein von dem Chor S: Michael, sondern von denen alhiesigen Hh: Compositoribus selbsten, als mit welchen ich ohnedem genugsamb bekandt [...]”. AMB, fond 1/9, inv. no. 18, sign. C 43, cart. 36, folder 70 .

10 "[...] meine neue musicalien, so ich von Wienner: guter bekantschafft, auch von Kays: Hoff selbstein, jedoch nicht ohne unkosten, überkomme, und mit grosser mühe zu kündftige überlassung der kirchen eigenhändig, wie ich dan auch schon bereits biss 2 tausend bögen verfertiget, abcopire, massen die kirchen sehr gross, die dienst viel, auch immer zuwachsen und die compositiones musices auf das höchste steigen [...]". Ibid, folder 82 . 
fifteen folded sheets (i.e. two-folios) per composition the number totals two hundred pieces at most. ${ }^{11}$

Over the following years, Rusmann extended the collection and was clearly in need of funding. The city council consequently had to deal with a dispute in 1730 over a rather large amount of $15 \mathrm{fl}$ which Rusmann had not paid to choralists for extra music events, which he intended to use to acquire new compositions from Vienna. ${ }^{12}$

After Rusmann's death on 28 December 1762, his precious collection was subject to a dispute between the heirs and the city council. It was common practice that music sheets were the musician's private property in the $18^{\text {th }}$ century. When changing their workplace, they took the sheets with them and following their death, they were subject to business transactions. In the case of Matthaeus Rusmann, however, the situation was different. He was employed at St. James' under the condition that after his death, all music sheets in his property as well as all those obtained subsequently during his activity in the St. James' choir, should be left to the church. ${ }^{13}$ He confirmed this commitment in his request for a salary rise from $1723 .{ }^{14}$ However, when the situation arose, his relatives refused for a long period of time to hand over the collection, as it was intended to support the admission of Rusmann's son Cajetan as the new regenschori. ${ }^{15}$ His efforts were also supported by his mother Susanna, who stated that the collection of her late husband consisted of almost 1,000 music sheets. ${ }^{16}$ Cajetan Rusmann was not chosen for the job in the end and the dispute had to be handled by the city council. ${ }^{17}$

Eventually, the relatives were forced to hand over the collection to the newly appointed regenschori, Peregrin Gravani. The handover is described by Bohumír Štědroň in his study Mozartovi vrstevníci v Brně [Mozart's Contemporaries in Brno]: “[Cajetan] Rusmann took the music sheets from two chests and a wardrobe; he had music sheets in his bed under the pallet, and they amounted to nine coal scuttles. Other music sheets belonging to the church were found in Mrs. Rusmann's house. These were three piles of music sheets hidden in the kitchen." 18 Upon

11 The estimated number of sheets is based on the common choir music ensemble (CATB, 2 violins and organo) with two to four sheets per one part.

12 ŽU゚REK, Pavel. Questenbergovi hudebníci v Brně. I. díl. Opus musicum 42, 2010, Nr. 5, p. 50-64.

13 The reply of the city council to Rusmann's application for the position of regenschori from 17 October 1721 (AMB, source cit. in the note 6, folder 71).

14 Cf. the note 10.

15 Cajetan's application for the post of regenschori from 29 December 1762 (AMB, source cit. in the note 6, folder 220-221).

16 “[...] Messen, mehr dann 100 Littaneyen, dem anderweitig Offertorien, Vespern, Arien, Requien [!], und mehrere solche Musicalien welche sich in der anzahl wenigstens auf 1000 Stücke erstruketen [!], und workom [!], wann Man den Bogen-Schreiber-Lohn mit samt dem Papier selbeten nur a 1 1/2xr in aufrechnung bringete über 1000 fr. an denen Kosten zustehen kommeten, all-diese seine eigene Musicalien zur allhiesig- wohlgesagten Pfarr-Kirchen ohnentgeltlich consecrirter haben wolle”. Application of Susanna Rusmannin from 29 December 1762 (Ibid, folder 224).

17 For more information on the dispute over Rusmann's music sheets, see ANDERKOVÁ, Natália. Kauza Rusmann (1763): brnenský regenschori od sv. Jakuba a jeho pozostalost'. Bachelor diploma thesis, Brno 2013.

18 ŠTĚDROŇ, Bohumír. Mozartovi vrstevníci v Brně. Bertramka. Věstník Mozartovy obce v Československé Republice, 2, 1950, Nr. 5-6, p. 1-3; 3, 1951, Nr. 2, p. 2-5; Nr. 5, p. 1-4. 
the handover, the collection included more than 150 masses, over 50 litanies, a slightly smaller amount of vespers, several hundred arias and other similar works. ${ }^{19}$

\section{The 1763 Inventory}

Apparently due to the difficulties with the handover of Rusmann's collection, a decision was made to elaborate its inventory, which became one of the most important documents related to music life in Brno around the 1750. According to the text and signatures at the end of the inventory, those responsible for the handover of the music sheets on the part of the municipality were "Kirchen-Vervalter" Johann Jacob Schwarz and "zur Inventierung deren diesfällig Musicalien denominierter Commissarius” Norbert Peter Paul Hadrawa. The inventory was written up in three copies. One of them was supposed to remain in the city hall (Sessionzimmer), the other at the new regenschori, and the third with commissioner Hadrawa. ${ }^{20}$ The preserved copy is apparently the one that was handed over to the regenschori together with the music sheets on 3 June 1763, as documented by the text at the end of the inventory and Gravani's signature.

In her study Hudba na jakubském ki̊ru [Music in the St. James choir], Theodora Straková mistakenly assumed that it was Rusmann who began the work on the inventory. ${ }^{21}$ It is also impossible to verify her statement that it was apparent from the inventory which items came from the property of the previous regenschori Altmann and which ones were acquired later. ${ }^{22}$ The most detailed investigation of the inventory was conducted by Miroslav Krejčí in his master's thesis Inventář hudebnin kostela sv. Jakuba [The inventory of music sheets from St. James church]. ${ }^{23}$ A transcription of the inventory, where the author also attempted to compare the inventory records to the preserved music sheets (or more precisely, only their catalogue cards), was attached to the thesis. Unfortunately, after an investigation in the records it turns out that the call marks were incorrect in a significant number of cases. Notwithstanding this fact, the thesis still provides some useful information, such as a list of the copyists of the St. James' music sheets identified up until that time, or a list of Gravani's compositions included in the collection.

19 “[...] von denen Rusmanisch übernommenen Musicalien befünden sich an Messen von verschiedenen Authoren über ein hündert fünftzig Stück, litaneyen mehr als 50 Stück, Wespern zwar nur wenig [...] Arien undt anderen dergleichen Musicalien auf baar hundert Stück". The handover protocol from 14 June 1763 (AMB, source cit. in the note 6, folder 226-228).

20 MAŇAS, Vladimír. Brněnská městská rada a hudební provoz ve farním kostele sv. Jakuba ve druhé polovině 18. století. Miscellanea z výročnich konferencí České společnosti pro hudebni vědu, Praha 2010, p. 74-77.

21 STRAKOVÁ, Theodora. Hudba na jakubském kưru v Brně od 2. pol. 17. do začátku 19. století. Sborník prací filozofické fakulty brněnské univerzity, H 19-20, 1984, p. 105-112.

22 Altmann's music sheets are not included in the inventory at all, although Rusmann's collection contained at least two hundred "Altmannische Messen" in the old style (AMB, source cit. in the note 6, folder 226-228).

23 KREJČÍ, Miroslav. Inventář hudebnin kostela sv. Jakuba v Brně z r. 1763 se zvláštním zřetelem k Peregrinu Gravanimu. Diploma thesis, Brno 1957. 
The inventory, stored in the Brno City Archives in the collection of the St. James' Library, ${ }^{24}$ is a bound book containing $134+2$ sheets: fol. $3 \mathrm{r}-134 \mathrm{v}$ have modern pagination done in pencil in the upper outer corner (p. 1-264). ${ }^{25}$ Apart from flyleaf sheets at the beginning and the end of the volume, the manuscript consists of sixteen folders labelled "Ternio". The first two folders are made of paper different from the rest of the manuscript, which is apparently why Straková assumed that the inventory was begun already by Rusmann..$^{26}$ As concerns the layout of the text, there was an obvious effort to start a new folder for each category (Ternio 1 - Missae, Ternio 4 - Lytaniae, Ternio 6 Vesperae etc.). The division into folders is clear in the section of litanies, where the first fifteen records are written twice: first in folder No. 3, where these records are crossed out as incorrect, and subsequently recorded correctly at the beginning of folder No. 4 .

The inventory was written by multiple scribes; the lead scribe, with a significantly curved form of the F-clef, is the author of several records of masses (No. 23-30) and the majority of other categories. There are blank pages left for subsequent records of compositions acquired later for every category. Considerable space for new acquisitions was left, specifically after the appointment, as the new regenschori, Gravani was required by the city council to obtain new compositions monthly and record them in the inventory. ${ }^{27}$ Gravani's records of the newly acquired music sheets constitute the second layer of records. They are added at the end of every particular category and labelled "de novo comparatae", in some cases complemented with a date. ${ }^{28}$

Apart from the text documenting the handover of the music sheets (p. 261-263), the final part of the inventory also includes an index of recorded compositions (p. 261):

24 Archiv města Brna [Brno City Archives], fond V 2, manuscript no. 16/5.

25 Binding: board cover with dimensions $357 \times 237 \mathrm{~mm}$, covered with dark brown leather, originally equipped with two pairs of fastening straps (one strap is missing). The front cover used to bear a decorative paper tag which has been torn off. The structure of the manuscript: $1+2+{ }_{1}$ VIII $(p .1-16)+{ }_{2} X(p .17-36)+$ ${ }_{3}$ VIII (p. 37-52) $+{ }_{4} \mathrm{X}\left(\right.$ p. 53-72) $+{ }_{5}$ VIII $\left(\right.$ p. 73-88) $+{ }_{6}$ VIII $\left(\right.$ p. 89-104) $+{ }_{7}$ VIII $\left(\right.$ p. 105-120) $+{ }_{8}$ VIII $($ p. 121-136) $+{ }_{9}$ VIII (p. 137-152) $+{ }_{10}$ VIII (p. 153-168) $+{ }_{11}$ VIII $\left(\right.$ p. 169-184) $+{ }_{12}$ VIII $\left(\right.$ p. 185-200) $+{ }_{13}$ VIII $($ p. 201-216) + ${ }_{14}$ VIII (p. 217-232) + ${ }_{15}$ VI (p. 233-244) + ${ }_{16}$ VIII (p. 245-260) + 2 (p. 261-264) + 1, where Arabic numerals in the subscript identify the folder ordinal number, Roman numerals define the number of folios in the folder, and Arabic numerals at the beginning and the end describe the number of flyleaves. Modern pagination is added to enable easier orientation.

26 Paper of the folders No. 1-2: $351 \times 222$ mm, watermark "crowned W". Paper of the rest of the manuscript: $357 \times 240 \mathrm{~mm}$, watermark "burning heart".

27 MAŇAS, Vladimír. Brněnská městská rada a hudební provoz ve farním kostele sv. Jakuba ve druhé polovině 18. století. Miscellanea z výročních konferenci České společnosti pro hudebni vědu, 2010, p. 74-77.

28 The group of Gravani's additions to the inventory was investigated by Helena Kramářová in Neu besorgte Musikalien für die Stadtpfarrkirche St. Jakob in Brünn zwischen den Jahren 1763 und 1781. 
Wiederhollung Deren Kirchen Musicalien

$\begin{array}{llll} & \text { Stück } & & \text { Stück } \\ \text { Messen } & 169 & \text { post Resur[r]ectionem } & \\ \text { Litaniae } & 64 & \text { Offertoria } & 110 \\ \text { Missae de Requiem } & 7 & \text { Canto Solo } & 61 \\ \text { Ad Requiem pertinentia } & 5 & \text { Alto Solo } & 18 \\ \text { De Profundis } & 15 & \text { Tenore Solo } & 5 \\ \text { pro octava fidelium defun[ctorum] } & 15 & \text { Duetto } & 9 \\ \text { Vesperae } & 18 & \text { Basso solo } & 19 \\ \text { Completoria } & 5 & \text { Post Pentecosten } & 15 \\ \text { Psalmi } & 18 & & \\ \text { De Adventu } & 30 & & \\ \text { Hymni } & 19 & & \\ \text { Introitus } & 15 & & \\ \text { p[ro] festo Corporis Christi } & & & \\ \text { Sancti Marci } & & \\ \text { diebus Rogationum } & & \\ \text { Passion Bücher } & & \\ \text { Coena Domi[ni] } & & \\ \text { Pumper Metten } & & \\ \text { Pro Resu[r]rectione Dom[ini] } & & \end{array}$

For the majority of sections, the number of individual records is added. Their total amount equals 617 , but this number does not correspond to the total amount of music sheets recorded. The number of compositions for the section Pro Festo Corporis Christi is omitted completely. The section even includes the following records in the index concerning small sub-groups or individual records. Sancti Marci refers for instance to a single record Antiphona p. Festo Scti. Marci, while Pumper Metten refers to a group of eight records. In total, the section Pro Festo Corporis Christi consists of 18 records. Similarly, the number of records in the index is missing for the section Post Resurrectionem, which consists of 6 records and the same number of references to selected offertories recorded elsewhere which may be used in this liturgical period. ${ }^{29}$ Since these records are only references to records in different parts of the inventory and are listed without an incipit, they are not included in the total amount.

The index also omits the entire sections or music sheets that were demonstrably part of the inventory already in 1763. These are Veni sancte spiritus (6 records), Stabat Mater (4), Salve Regina (41) or Te Deum (8). The latter two sections, Salve Regina and Te Deum, are the subjects of an interesting finding. Not only are they missing in the index, but also the handwriting differs significantly. The last two pages in the section Salve Regina were

29 E.g. "vide N. 22 sub titulo Canto solo de Nativi[tate] et Resurrectione". 
demonstrably recorded by Gravani (records 22-41). This led to a hypothesis that these records refer to music sheets not originally included in the inventory, and thus belonging to the category of new acquisitions Gravani was required to obtain and subsequently add to the inventory. A detailed analysis has proved, however, that all of them were part of Rusmann's property. They cannot have been obtained by Gravani, nor are they labelled as new acquisitions. In addition, the names of the sections concerned are written by the same hand as other parts of the inventory. The same situation occurs with the category Miserere, where only one new piece from 1768 is recorded, although Rusmann's collection includes several works of this kind. The most probable explanation is that after the delay with the acquisition of Rusmann's collection, the handover of the inventory was hasty and the copy given to Gravani was not completely finished. It was apparently Gravani's task to add these last recorded groups after the inventory was given to him, which he fulfilled only to a certain extent.

Table 1 provides an overview of the content of the inventory. The total number of the originally recorded inventory items is 715 . The second layer of records consists of Gravani's actual records of newly acquired music sheets. The number of these newly recorded compositions is 193. In total, the inventory contains 908 individual records. The inventory includes exclusively vocal church compositions; there are no instrumental ones. A significant part of the compositions are anonymous ones: 332 from the original incipits and 17 of those recorded subsequently by Gravani.

\begin{tabular}{|c|c|c|c|c|}
\hline Extent & Name of the section & Total & Original & Newly recorded \\
\hline pp. 1-40, 43-46, 215-216 & Missae Solennes & 269 & 169 & 100 \\
\hline pp. 47-48 & Veni Sancte Spiritus & 6 & 6 & - \\
\hline p. 47 & Stabat Mater Dolo: & 4 & 4 & - \\
\hline (pp. 49-51), p. 53-67, 217 & $\begin{array}{l}\text { Lytaniae solennes, ordinariae } \\
\& \text { breves }^{30}\end{array}$ & 88 & 64 & 24 \\
\hline pp. 69-71 & Missae De Reqviem ${ }^{31}$ & 17 & 11 & 6 \\
\hline p. 77 & Ad Reqviem pertinentia & 5 & 5 & - \\
\hline pp. 79-80 & Fidelium Defunctorum & 15 & 15 & - \\
\hline pp. 83-84 & $\begin{array}{l}\text { Pro octava fidelium Defunctis } \\
{[!]}\end{array}$ & 15 & 15 & - \\
\hline pp. 89-94, 217-218 & Vesperae & 39 & 18 & 21 \\
\hline p. 94 & $\begin{array}{l}\text { (Responsoria pro Sacra Hebdo- } \\
\text { mada) }\end{array}$ & 3 & - & 3 \\
\hline p. 99 & Completoria & 5 & 5 & - \\
\hline pp. $100-102,105-108$ & Psalmi ${ }^{33}$ & 29 & $11+18$ & - \\
\hline pp. 121-126 & De Adventu & 30 & 30 & - \\
\hline
\end{tabular}

30 On the p. 49-51, the records No. 1-15 are crossed out and newly written on the p. 53-55. These are not included in the total number of records.

31 Records No. 8-11 are added later, but by the same writer.

32 No regular name of the section, but only an addition from 1773.

33 Psalms are recorded at two different places: first group from the p. 100 as No. 6-15 in the section Completoria (No. 10 is used twice, erroneously) and second group normally from p. 105 (No. 1-18, as recorded in the index). Both of them contain Rusmann's music sheets. 


\begin{tabular}{|l|l|c|c|c|}
\hline Extent & Name of the section & Total & Original & Newly recorded \\
\hline pp. 129-131 & Hymni / Haec Dies & 19 & 19 & - \\
\hline p. 133 & Pro festo Corporis Xti & 5 & 5 & - \\
\hline p. 134 & Pro coena Domini & 5 & 5 & - \\
\hline pp. 135-136 & Zur Pumper Metten & 8 & 8 & - \\
\hline pp. 137-138 & Introitus & 15 & 15 & - \\
\hline pp. 145-146 & Post Resurrectionem & 6 & $\begin{array}{c}6(+6 \\
\text { referen- } \\
\text { ces) }\end{array}$ & - \\
\hline pp. 151-173, 212-214, 218- & Offertoria & & 110 & 38 \\
\hline pp. $175-187$ & Canto Solo & 148 & - \\
\hline pp. 191-194 & Alto Solo & 61 & 61 & - \\
\hline p. 199 & Tenore Solo & 18 & 18 & - \\
\hline pp. 203-204 & Duetto & 5 & 5 & - \\
\hline pp. 205-208 & Basso Solo & 9 & 9 & - \\
\hline pp. 211-212 & Post Pentecosten & 19 & 19 & - \\
\hline pp. 233-237 & Salve Regina & 15 & 15 & - \\
\hline pp. 239-240 & Te Deum Laudamus & 41 & 41 & - \\
\hline p. 257 & Miserere & 1 & - & 1 \\
\hline & IN TOTAL & 908 & 715 & 193 \\
\hline
\end{tabular}

Tab. 1 Content of the St. James inventory

The numbering of the entries in the individual categories always begins with 1 and is continuous with the exception of the masses, where for an unknown reason, following entry 199, the numbering goes back to 100 . Numbers 100-158 are thus used twice in this section. The first record refers to the original layer of the collection, while the second one refers to the subsequent additions. Similarly, with the newly added records in the category of litanies, number 77 follows by mistake after 66 , and in the first section of Psalms, number 10 is used twice. The continuity of the numbering is also disrupted with some newer additions, where ordinal numbers are missing for the entire groups of records. The numbers in the inventory correspond to the inventory numbers on the individual music sheets placed on the title page in the upper right corner (see Fig. 1). ${ }^{34}$

Every inventory record consists of two parts. The heading usually states the surname (and in some cases also the first name) of the author and the scoring, followed by the inventory number and the musical incipit. The incipits usually include the basso continuo part supplemented with the initial words of the lyrics (see Fig. 2).

This is, however, not a general rule for all the records. For instance, in Masses, apart from the beginning of Kyrie, the beginning of Christe is also provided on a separate line; in section Canto Solo, the leading vocal part is usually provided. In the category of

34 The music sheets also carry three other kinds of evidence numbers: the upper central part usually bears the sheet's ordinal number from the property of Matthias Franz Altmann, the bottom left corner bears an evidence number from the $19^{\text {th }}$ century, and a small portion of music sheets also carry another numeral code from the $19^{\text {th }}$ century on the back cover. 


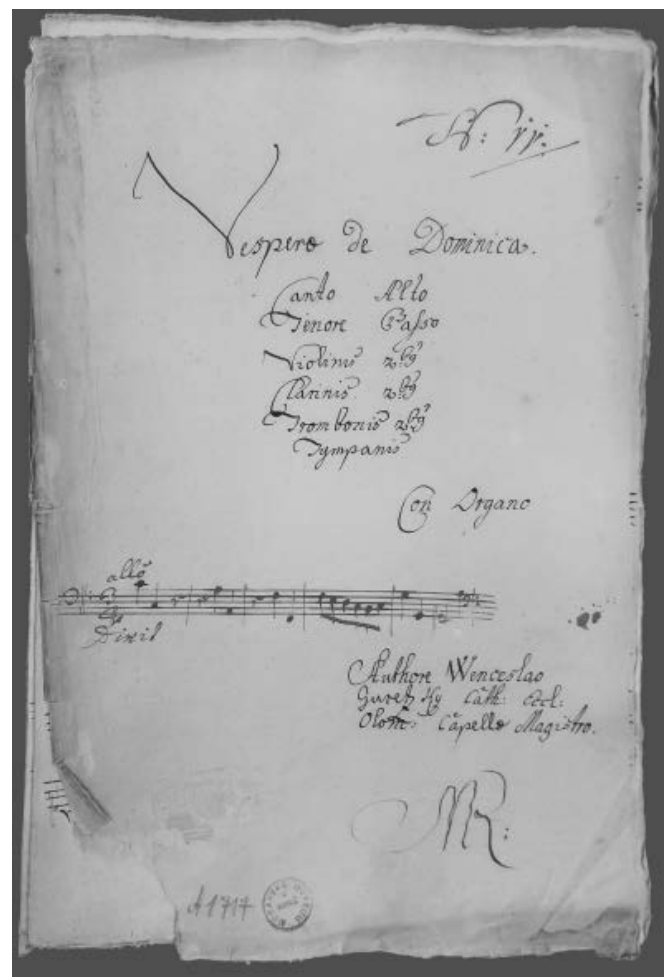

Fig. 1 Title page of the Guretzky's Vesperae de Dominica. Moravské zemské muzeum, Oddělení dějin hudby [Department of the History of Music at the Moravian Museum], call mark A 1717

Offertories, the records do not adhere to any particular rule. In some cases, the record provides a two-stave incipit of basso continuo and the soprano part, basso continuo and the initial part of the recitative, or only a record of the vocal part.

When elaborating the inventory, a distinctive feature of the individual compositions was apparently not their name: although the names are provided on title pages, they are not reflected in the inventory at all. This poses considerable difficulty when identifying the individual works in the amount of music sheets preserved up until the present. Ehrenhart's

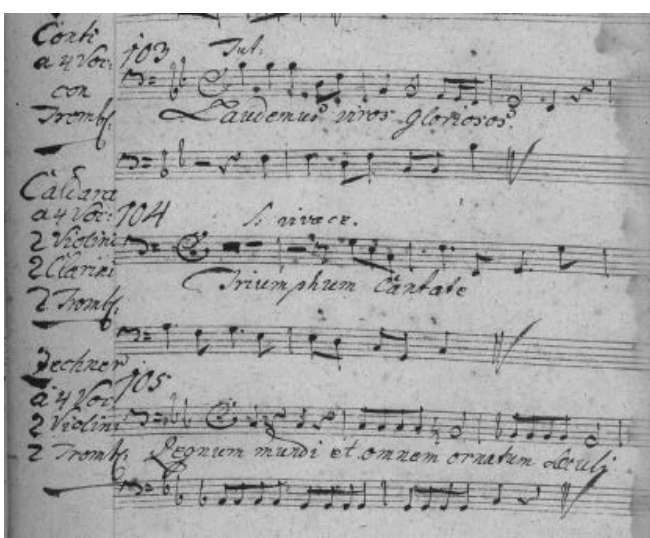

Fig. 2 An inventory record (main scribe), Archiv města Brna [Brno City Archives], fond V 2, manuscript no. $16 / 5$

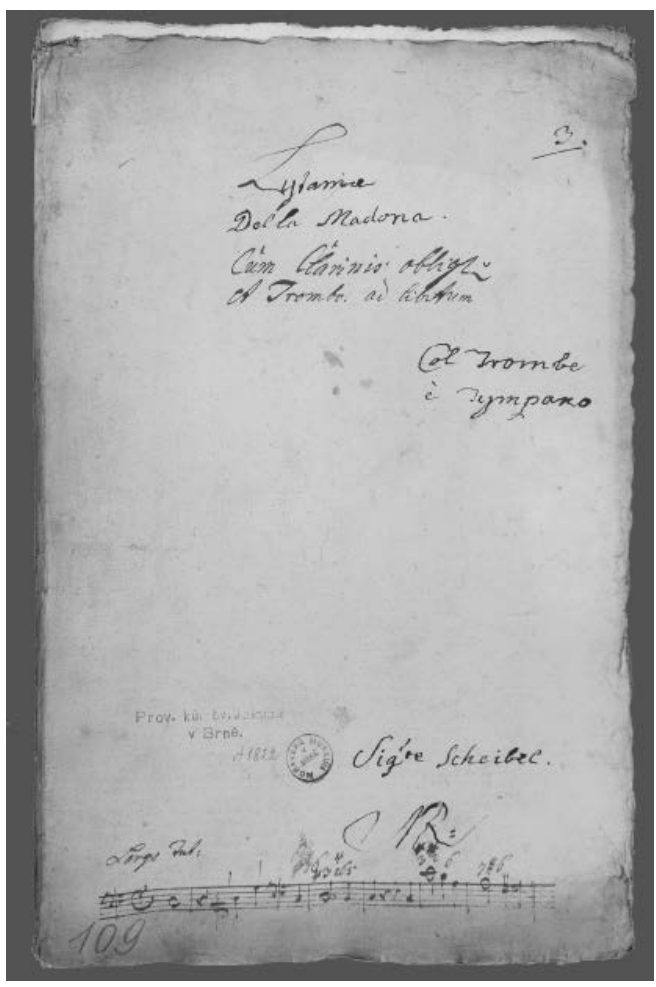

Fig. 3 Title page of the Scheibl's Litaniae della Madona. Moravské zemské muzeum, Oddělení dějin hudby [Department of the History of Music at the Moravian Museum], call mark A 1822 
Missa Consolatrix Afflictorum (A 2146) is recorded, for example, in the inventory only as Ehrenhart Cum Clarinis oblig: (inv. 15/74) and Pichler's Missa Spero in Dominum (A 2207) as Pichler Cum Trombo: oblg: (inv. 16/78). ${ }^{35}$ In contrast, it seems that instrumentation was a significant feature, especially the obligatory wind instruments, as in some of the music sheets they are subsequently added on the title page (see Fig. 3).

\section{Preserved Music Sheets from Rusmann's Property}

The main objective of the research was to compare the music sheets deposited at the Department of History of Music in the Moravian Museum to records in the inventory and determine the content of the original collection of Matthaeus Rusmann, as well as investigate its current state. When identifying the music sheets, we observed the following features:

1) Rusmann's initials "MR" as the owner's sign on the cover;

2) an inventory number identical to the record in the inventory;

3) the identity of the incipit recorded in the inventory compared to the incipit on the title page of the particular music sheet (or the incipit of the respective vocal or instrumental part). ${ }^{36}$

There are, however, numerous exceptions to this description of an ideal state of music sheets. A number of the owner's initials are missing, or the cover has not been preserved so it is actually almost impossible to determine anything at all. In such cases, our classification of a music sheet within Rusmann's collection was based primarily on the handwriting (identifying a copyist is a reliable method for classification of compositions into a particular period). There was subsequently a need to compare the music notation to all the unidentified incipits in the inventory.

At the moment, 359 compositions from the total number of 908 records in the inventory are preserved and unambiguously identified. Out of these, 286 works belong to the property of Matthaeus Rusmann and are consequently part of the 715 music sheets recorded in the inventory in $1763 .{ }^{37}$

This is, however, not the final number of currently existing Rusmann's music sheets. A rather considerable number (dozens of items) of compositions from the St. James' collection demonstrably come from his property, but cannot be found in the inventory. These compositions often do not bear any inventory number, so it is possible that they were not recorded in the inventory at all. We can therefore assume that Rusmann's relatives, despite the directive from the city council, did not hand over all the music sheets to

35 In the following references to the inventory, the first number refers to the page and the second to the ordinal number on the particular page.

36 In many cases, the incipit is not provided at all on the title page (e.g. A 1620, A 1716, A 1971), so the respective parts had to be examined.

37 Another 73 pieces come from the property of Peregrin Gravani and belong to the 193 subsequently added records. 
the church. If we are to believe the statement of the widow after the regenschori, these were almost three hundred compositions in all. It seems apparent that his son Cajetan, who continued working at the St. James' choir, kept them. After his death, the music sheets might have been left in the church. It should be added, however, that a considerable number of compositions, that were found in the inventory based on the musical incipit, also do not bear any ordinal number. The following are examples of this case:

1. Miserere by Ignaz Prustmann (A 1775) is marked on the cover as a composition from the property of M. Rusmann; a comparison of the handwriting demonstrates that Rusmann copied the composition himself. It is not recorded, however, in the inventory and has no ordinal number.

2. Anonymous Dextera Domini (A 1971) also comes from Rusmann's property, according to the owner's mark, and was also copied by himself, but has no ordinal number. Nevertheless, it is recorded in the inventory on page 134 as Graduale ad montem olivarum (an unnumbered record in the category Pro Coena Domini).

In some cases, it is almost impossible to determine the music sheets from Rusmann's property. If all the identification features are missing, the composition was copied by an unknown copyist and its author is one of those whose compositions were purchased by Gravani and the identification becomes a moot point. In addition, Gravani continued to use Rusmann's original compositions. He usually replaced the cover of the particular music sheet, had the impaired parts newly copied (which was one of his tasks as regenschori) and possibly also composed an additional solo voice part. An example is Requiem (A 2295), where the author stated on the cover is Zechner, and Rusmann is marked as the owner. The music sheet includes, however, some parts added by Gravani, and he also recorded it in the inventory in 1769 (apparently due to a missing number) as a newly acquired composition by Georg Donberger. ${ }^{38}$

In addition, some compositions in Rusmann's collection cannot be found because they were later scattered to other church choirs in Brno (and probably also in other places). This is the case of Conti's motet Laudemus viros gloriosos composed for the anniversary celebration of the Moravian fraternity in St. Michael's church in Vienna. The fact that it belongs to Rusmann's collection is unambiguously proven by the copyist's handwriting and the initials "MR" on the title page. The composition is also recorded in the inventory in the section Offertoria (inv. 171/103). The same case is Caldara's Stabat Mater, recorded in the inventory as an anonymous work (inv. 47/3). Both these compositions are currently part of the Minorite collection in Brno. ${ }^{39}$

There are a few problematic items that have not yet been identified, but we can state that the total number of music sheets from the collection of Matthaeus Rusmann pre-

38 In fact, it is actually Donberger's composition (Hug II,1). It is of interest that Zechner is also stated as its author in Loreta church in Prague. Cf. HUG, Raimund. Georg Donberger (1709-1768) und die Musikpflege im Augustiner-Chorherrenstift Herzogenburg, Sinzig 2007, vol. 2, p. 102-104 (but the author mentions only the record in the St. James' inventory, while the music sheet has not been identified by him due to an incorrect author attribution).

39 Caldara: A 17.308. Conti: A 17.310. For more information about the last work mentioned, see SPÁČILOVÁ, Jana. Contiho moteto k poctě svatých Cyrila a Metoděje. Vlastivědný věstnik moravský 65, 2013, Nr. 2, p. 140 146. 
served until the present day in the St. James' collection is 345 . For clarity, an overview of Rusmann's compositions in relation to the inventory follows:

\begin{tabular}{|l|l|}
\hline Total number of entries in the inventory & 908 \\
\hline Incipits of Rusmann's collection & 715 \\
\hline Newly added & 193 \\
\hline Total number of Rusmann's compositions in the St. James' collection & 345 \\
\hline Identified in the inventory & 286 \\
\hline Outside the inventory & 59 \\
\hline
\end{tabular}

\section{Structure of the Repertory in Rusmann's Collection according to the Inventory}

The following Table 2 provides an overview of the composers included in Rusmann's collections, as identified according to the 1763 inventory. The table contains all the names included in the original layer of the inventory without subsequent additions and the respective numbers of compositions. The second column of the table refers to preserved music sheets corresponding to the particular records in the inventory. ${ }^{40}$ The order of the signatures reflects theirs order in the inventory. There are more preserved and identified compositions of authors below, however these compositions are not written in the inventory and are not included in this table.

\begin{tabular}{|l|c|l|}
\hline $\begin{array}{l}\text { Name (or variants listed } \\
\text { in the inventory) }\end{array}$ & $\begin{array}{l}\text { Records } \\
\text { in the inventory }\end{array}$ & Preserved music sheets \\
\hline Anonym & 332 & \\
\hline Aufschnaiter, Benedikt Anton & 1 & \\
\hline Bach, Johann Sebastian (Pach) & 1 & \\
\hline Bassani, Giovanni. Battista & 1 & \\
\hline Beyer, Johann Ignaz & 5 & A 2194, A 1544, A 1543, A 1542 \\
\hline Boog, Johann Nepomuk & 1 & A 2125 \\
\hline Brixides, Johannes & 1 & A 2140 \\
\hline Bruneder (Pruneder), Franz Gerhard & 5 & A 1553, A 1554, A 1774 \\
\hline Caldara, Antonio & 68 & $\begin{array}{l}\text { A 2136, A 2338, A 2334, A 2315, A 2367, A 2348, } \\
\text { A 157241, A 2127, A 21284, A 2137, A 2133, A 2131, } \\
\text { A 2130, A 2129, A 2135, A 2132, A 2134, A 1559, } \\
\text { A 1581, A 1562, A 1563, A 1560, A 1561, A 1573, } \\
\text { A 1557, A 1572, A 1583, 1584, 1567, 1564, 1579, } \\
1582,1580,1566,1558,1568,1565,1556, A 1578, \\
\text { A 1574, A 1575, A 1576, A 1577 }\end{array}$ \\
\hline Carl, Anton & & A 1588, A 1585 \\
\hline
\end{tabular}

40 Italic is used for the call marks with disputable authorship.

41 Caldara in the inventory, no name of composer on the title page.

42 Caldara and Brixides on the title page of the composition, Brixides is the author. 
The Music Collection of the Brno St. James Regenschori Matthaeus Rusmann and its Inventory ...

\begin{tabular}{|c|c|c|}
\hline $\begin{array}{l}\text { Name (or variants listed } \\
\text { in the inventory) }\end{array}$ & \begin{tabular}{|l|} 
Records \\
in the inventory
\end{tabular} & Preserved music sheets \\
\hline Conti, Francesco Bartolomeo & 7 & A 2139, A 2371 \\
\hline Donberger, Georg Joseph & 17 & $\begin{array}{l}\text { A 2142, A 2141, A 2144, A 2143, A 1599, A 1598, } \\
\text { A 1600, A 190443, A 214544 }\end{array}$ \\
\hline Ehrenhardt, Johann Franz (Ehrnhardt) & 5 & A 2146, A 2147, A 1628, A 1608, A 1609 \\
\hline Eisenbach [?] & 1 & \\
\hline Feo, Francesco & 1 & A 1614 \\
\hline Fux, Johann Joseph & 32 & $\begin{array}{l}\text { A 1624, A 1629, A 1630, A 1623, A 2373, A 1627, } \\
\text { A 1628, A 1622, A 1621, A1625, A 1626, A 2332, } \\
\text { A 1992, A } 2072^{45} \text {, A 177946 }\end{array}$ \\
\hline Gottwald, Joseph & 3 & A 1633, A 1634 \\
\hline Graff, Franz Leopold & 3 & \\
\hline Gravani, Peregrinus & 1 & A 2152 \\
\hline Gurecký, Václav Matyáš & 2 & A 1717 \\
\hline Hasse, Johann Adolf & 3 & A 1721 \\
\hline Holzbauer, Ignaz & 2 & A 46964, A 2163 \\
\hline Jacob, Gunther OSB & 1 & \\
\hline P. Justus Joseph [Keinz?] & 1 & \\
\hline Klíma, Benedikt & 1 & \\
\hline Koller, Georg (Köller) & 1 & \\
\hline Kolberer, Cajetan & 1 & \\
\hline Laube, Anton & 6 & A 2181, A 2178, A 2180, A 2179 \\
\hline Lotti, Antonio & 1 & \\
\hline Mayer, Rupert & 2 & A 1750 \\
\hline Müller (Miller) [?] & 1 & A 1755 \\
\hline Neumann [?] & 1 & A 1760 \\
\hline Oettel, Matthias & 6 & A 2199, A 2201, A 2200, A 1764 \\
\hline Paradies, Domenico & 1 & \\
\hline Petz, Johann Christoph & 1 & \\
\hline Pichler, P. Augustin (Bichler) & 3 & A 2207, A 2206 \\
\hline Porpora, Nicola & 1 & \\
\hline Reinhardt, Johann Georg & 24 & $\begin{array}{l}\text { A 2215, A 2212, A 2213, A 2216, A 2218, A 2214, } \\
\text { A 2217, A 1780, A 1778, 1777, A 1776, A 2223, } \\
\text { A 2221, A 1783, A 1782, A 1785, A 234947 }\end{array}$ \\
\hline Reutter, Georg (jr.?) & 25 & $\begin{array}{l}\text { A 2242, A 2235, A 2238, A 2234, A 2243, A 2226, } \\
\text { A 2232, A 2240, A 2227, A 2236, A 1789, A 1790, } \\
\text { A 1792, A 1791, A 2363, A 179348 }\end{array}$ \\
\hline Růžička, Jan & 1 & A 1798 \\
\hline Sarri, Domenico & 1 & A 1807 \\
\hline Seemann, Thomas & 2 & A 1809, A 1810 \\
\hline
\end{tabular}

43 Donberger in the inventory, Zechner on the title page of composition.

44 Donberger in the inventory, Cadara on the title page of composition.

45 Fux in the inventory, no name of composer on the title page of composition.

46 Fux in the inventory, Reinhardt on the title page of the composition

47 Reinhardt in the inventory, no name of composer on the title page of composition.

48 Reutter in the inventory, no name of compser on the title page of composition. 


\begin{tabular}{|c|c|c|}
\hline $\begin{array}{l}\text { Name (or variants listed } \\
\text { in the inventory) }\end{array}$ & \begin{tabular}{|l|} 
Records \\
in the inventory
\end{tabular} & Preserved music sheets \\
\hline Scheibl, Johann Adam & 14 & $\begin{array}{l}\text { A 2257, A 2256, A 2255, A 2254, A 2251, A 1823, } \\
\text { A 1824, A 1821, A 1826, }\end{array}$ \\
\hline Schenk, P. Egidius & 1 & A 1829 \\
\hline Schmidt, Ferdinand & 21 & $\begin{array}{l}\text { A 2264, A 2265, A 2258, A 1836, A 1835, A 2259, } \\
\text { A 2262, A 2253, A 1841, A 1843, A 1939, A 1841, } \\
\text { A 1845, A 1844, A 1842 }\end{array}$ \\
\hline Sylvanus [?] & 1 & \\
\hline Treitler, Friedrich & 3 & A 1852, A 1853 \\
\hline Tůma, Franz Ignaz & 8 & A 2250, A 1854, A 1855 \\
\hline Umstatt, Joseph & 8 & $\begin{array}{l}\text { A 2268, A 2271, A 2270, A 2269, A 2272, A } 2218 \\
+ \text { A 236149 }\end{array}$ \\
\hline Wachter, Jacob & 5 & A 1866, A 1867, A 1799, A 1864, A 1865 \\
\hline Zacher, Johann Michael & 2 & A 1880, A 1882 \\
\hline Zechner, Johann Georg & 61 & $\begin{array}{l}\text { A 2291, A 2296, A 2288, A 2290, A 2283, A 2298, } \\
\text { A 2302, A 2293, A 2285, A 2289, A 2301 (sleeve } \\
\text { only, content A 2355), A 2282, A 2299, A 2304, } \\
\text { A 2286, A 2303, A 1892, A 1893, A 1895, A 1897, } \\
\text { A 1912, A 1914, A 1908, A 1913, A 1911, A 1909, } \\
\text { A 1888, A 1884, A 1885, A 1886, A 1899, A 1887, } \\
\text { A 1890, A 1901, A 1900, A } 1905 \\
\text { A 225250, A 157151 }\end{array}$ \\
\hline Ziani, Marc'Antonio & 7 & A 2309, A 2308, A 2311, A 2310, A 2307, A 1915 \\
\hline Ziegler, Joseph Paul & 1 & A 2306 \\
\hline IN TOTAL & 715 & \\
\hline
\end{tabular}

Tab. 2. Reconstruction of the Rusmann's collection according to the inventory

According to the 1763 inventory, 53 composers are represented in Rusmann's collection; almost half of them by one title only. One of the most interesting items is the offertory Dextera Domini composed as an adaptation of Bach's Musikalische Opfer (not preserved until the present). Religious compositions by Hasse, Sarro, Paradies and Porpora were apparently also created as contrafacta of opera arias. Compositions by Italian authors only play, however, a minor role in the collection profile, in contrast to those by the Prague Knights of the Cross or St. Vitus Cathedral in Prague. ${ }^{52}$ From the recorded compositions, only the manuscripts are still preserved, in spite of the fact that the collection contained many prints, e.g. Aquila clangens by Benedikt Anton Aufschnaiter (Passau 1719), Anathema gratiarum by Gunther Jacob (Prague 1714), Partus secundus, continens

49 A 2218 is a cover, A 2361 music sheet.

50 Zechner in the inventory, Scheibl on the title page of the composition.

51 Zechner in the inventory, Caldara on the title page of the composition.

52 Cf. FUKAČ, Jiří. Křižovnický hudebni inventář. Příspěvek k poznáni křižovnické hudebni kultury a jejího mista $v$ hudebním životě barokni Prahy. Diploma thesis, Brno 1959. ŠTEFAN, Jiří. Ecclesia metropolitana Pragensis catalogus collectionis operum artis musicae. Catalogus artis musicae in Bohemia et Moravia cultae, vol. IV. Praha 1983, 1985. 
Introitus breves by Cajetan Kolberer (Augsburg 1703), Psalmodia brevis ad vesperas totius anni by Rupert Mayer (Augsburg 1706) and Jubilum missale sextuplex Johann Christoph Petz (Augsburg 1706).

A prominent place in Rusmann's repertory belonged, as with other church collections of the time, to the Viennese court vice-Kapellmeister of Venetian descent Antonio Caldara (c. 1670-1736). Especially in the category of masses, he is by far the most frequently represented author. Three unique independent mass sections by Caldara rank among the most treasured pieces of music heritage preserved at St. James' ${ }^{53}$

The second position belongs to Johann Georg Zechner (1716-1778), with his more than 60 compositions closely following Caldara. This organist and composer was not active in Vienna; his life is connected to Göttweig, Krems and Stein an der Donau. Although his works were quite widespread, especially in religious circles, the St. James' collection is one of the richest sources of his compositions.

Other more prominently represented authors belong to the circles of Viennese composers. These are Johann Josef Fux (1660-1741), Johan Georg Reinhardt (1676/7-1742), Ferdinand Schmidt (1693/4-1756) and both Reutters. Particularly Georg Reutter Jr. (1708-1772), as a representative of the younger generation, has an important role not only in the Rusmann part of the collection, but also in the later acquisitions by Peregrin Gravani.

Other authors represented by more than ten compositions in Rusmann's collection are Georg Donberger (1709-1768), an organist from Herzogenburg, Johann Adam Scheibl (1710-1773), who worked in the Seitenstetten and St. Pölten monasteries, and Anton Carl (c. 1717-1784), a Viennese composer.

\section{Conclusion: Objectives for Further Research}

The representation of authors in Rusmann's collection should only be viewed as a tentative overview of the repertory, since the numbers of the compositions of the individual authors listed in the inventory frequently do not correspond to the original collection, nor to the compositions actually preserved. The main reason is the high amount of disputable author attributions. It is not unusual that the inventory states an author different from that on the title page of the particular music sheet, although the incipit and the inventory number match. In other cases, a composition is frequently recorded as an anonymous one, although the author is stated on the title page, and vice versa. The following are examples of disputable authorship:

1. In the inventory, Donberger is recorded as the author of mass 32/156. The preserved music sheet (A 2143) bears the name Donberger, as well as Öetl. ${ }^{54}$

53 SPÁČILOVÁ, Jana. Unknown Mass Compositions by Antonio Caldara in Moravian Music Archives. In Antonio Caldara nel suo tempo. Ed. Milada Jonášová - Tomislav Volek. L'opera italiana nei territori Boemi durante il settecento, 2, Praha 2017, p. 157-176.

54 It is Donberger's composition (Hug I,44A), cf. HUG, op. cit., vol. 2, p. 83-85. 
2. As concerns Requiem a 4 Vocibus (A 2259), the title page even provides three different authors: Scheibl, Schmid and Donberger. The inventory provides only one author for this record - Schmidt (inv. 69/2). As the inventory is at present the primary source of the research, the music sheet in the Table 2 is attributed to Schmidt, although the author of the composition is in fact Donberger. ${ }^{55}$

An illustration of the extensive problem regarding disputable author attributions may be Caldara's mass compositions. These are currently the only comprehensively investigated part of the St. James' music collection. In the period under consideration, Caldara was perceived as the epitome of this music-liturgical form and his name was frequently attributed to compositions of other authors. Using concordances, it was determined that from 46 mass compositions attributed to Caldara in Rusmann's part of the inventory, only 27 may be unambiguously attributed to him. The identified authors of the remaining ones are Jan Brixides, Georg Donberger, Nicola Fago, Matthias Oettl, Franz Gerhard Pruneder, Christoph Sonnleitner, Ferdinand Schmidt and Georg Zechner. In contrast, Caldara's authorship has been identified for mass attributed to Johann Georg Reinhardt (A 2213, inv. 19/91) and an anonymous Missa S. Jacobi (A 2335, inv. 4/17 as "Caldara", as well as "Schmid" within the Gravani's acquisitions on the p. 44). ${ }^{56}$

As is apparent from the above presented examples, a definite attribution of authorship, analysis, and comparison of St. James' music sheets is a task for the distant future. It is already possible to state, however, that with regard to its extent, author representation, and exceptional degree of preservation, the St. James' music collection ranks among the most important music collections in the Czech Republic. The 1763 inventory of music sheets from the property of Matthaeus Rusmann is not only a reflection of the state of the collection at a certain point in time, but also valuable evidence of the currently lost compositions.

Based on the analysis of the inventory and the preserved music sheets, the previously defined hypotheses may be confirmed. The activity of Matthaeus Rusmann as regenschori at St. James' actually resulted in a significant inclination in the music repertory towards Viennese or Austrian authors. A similar orientation is also apparent in other places in the Czech Lands,${ }^{57}$ but here it is exceptionally strong due to the regenschori's direct personal contacts in Vienna and his active interest in acquiring new music sheets. Compositions by Austrian authors, which are in many cases preserved exclusively at St. James', rank among the most valuable musical heritage from the Baroque period in the territory of the Czech Republic.

55 Hug II,2. Cf. HUG, op. cit., vol. 2, p. 104-108.

56 SPÁČILOVÁ, Jana. Moravské prameny mešní tvorby Antonia Caldary: problém autenticity. Hudebni věda 49, 2012, Nr. 1-2, p. 45-80.

57 A complete overview of the Moravian repertory based on preserved sources and original inventories is provided in SPÁČILOVÁ, Jana. Kirchenmusik Wiener Komponisten in Mähren in der ersten Hälfte des 18. Jahrhunderts. In Sakralmusik im Habsburgerreich 1570-1770. Ed. Tassilo Erhardt. Wien 2013, p. 285-300. 


\section{Bibliography}

\section{Sources}

Archiv města Brna [Brno City Archives], fond 1/9 Stará registratura, inv. no. 18, sign. C 43, cart. 36, Členové kůru sv. Jakuba 1678-1766 [Members of St. James choir 1678-1766]

Archiv města Brna [Brno City Archives], fond V 2, manuscript no. 16/5, Tématický inventář hudební sbírky kostela sv. Jakuba v Brně [Thematic inventory of music collection at St. James church in Brno].

Moravské zemské muzeum, Oddělení dějin hudby [Department of the History of Music at the Moravian Museum], Hudební sbírka farního kostela sv. Jakuba v Brně [Music collection of the St. James parish church in Brno], A 1517 - A 2375, A 3927 - A 4301, A 46574 - A 46723, A 46853 - A 47260, A 47635 - 47934, A 50521 - A 50527.

\section{Literature}

ANDERKOVÁ, Natália. Kauza Rusmann (1763): brnenský regenschori od sv. Jakuba a jeho pozostalost'. Bachelor diploma thesis, Brno 2013.

FUKAČ, Jiří. Křižovnický hudebni inventář. Přispěvek $k$ poznáni křižovnické hudebni kultury a jejiho mista v hudebnim životě barokni Prahy. Diploma thesis, Brno 1959.

HORYNA, Martin - MAŇAS, Vladimír. Two Manuscripts of Polyphonic Music in Brno from the Mid-Sixteenth Century. Early Music 40, 2012, Nr. 4, p. 553-575. See also MAŇAS, Vladimír. The choir lofts in the church of St. James in Brno (between the late 15th and the 19th centuries). Musicologica Brunensia 51, 2016, Nr. 1, p. 103-111.

HUG, Raimund. Georg Donberger (1709-1768) und die Musikpflege im Augustiner-Chorherrenstift Herzogenburg, Sinzig 2007.

KREJČÍ, Miroslav. Inventář hudebnin kostela sv. Jakuba v Brněz r. 1763 se zvláštním zřetelem $k$ Peregrinu Gravanimu. Diploma thesis, Brno 1957

KYAS, Vojtěch. Prüvodce po archivních fondech II. Odděleni dějin hudby Moravského zemského muzea (Př́riostky za léta 1971-2001 a doplňky), Brno 2007.

MAŇAS, Vladimír. Brněnská městská rada a hudební provoz ve farním kostele sv. Jakuba ve druhé polovině 18. století. Miscellanea z výročnich konferenci České společnosti pro hudebni vědu, 2010, p. 74-77.

MAŇAS, Vladimír. The choir lofts in the church of St. James in Brno (between the late 15th and the 19th centuries). Musicologica Brunensia 51, 2016, Nr. 1, p. 103-111.

SCHÜTZ, Karel. Musikpflege an St. Michael in Wien, Wien 1980

SPÁČILOVÁ, Jana. Contiho moteto k poctě svatých Cyrila a Metoděje. Vlastivědný věstnik moravský 65, 2013, Nr. 2, p. 140-146.

SPÁČILOVÁ, Jana. Kirchenmusik Wiener Komponisten in Mähren in der ersten Hälfte des 18. Jahrhunderts. In Sakralmusik im Habsburgerreich 1570-1770. Ed. Tassilo Erhardt. Wien 2013, p. 285-300.

SPÁČILOVÁ, Jana. Moravské prameny mešní tvorby Antonia Caldary: problém autenticity. Hudebni věda 49, 2012, Nr. 1-2, p. 45-80.

SPÁČILOVÁ, Jana. Unknown Mass Compositions by Antonio Caldara in Moravian Music Archives. 
In Antonio Caldara nel suo tempo. Ed. Milada Jonášová - Tomislav Volek. L'opera italiana nei territori Boemi durante il settecento, 2, Praha 2017, p. 157-176.

STRAKOVÁ, Theodora - SEHNAL, Jiří - PǨIBÁŇOVÁ, Svatava. Pri̛vodce po archívnich fondech Ústavu dějin hudby Moravského musea v Brně, Brno 1971.

STRAKOVÁ, Theodora. Hudba na jakubském kůru v Brně od 2. pol. 17. do začátku 19. století. In Sbornik prací filozofické fakulty brněnské univerzity, H 19-20, 1984, p. 105-112.

STUDENIČOVÁ, Hana. Kantoři, varhaníci a věžní u sv. Jakuba v Brně v 16. století. In Brno v minulosti a dnes. Př́spěvky $k$ dějinám a výstavbě Brna, Archiv města Brna, 2017, roč. 30, prosinec, s. $127-145$.

ŠTĚDROŇ, Bohumír. Mozartovi vrstevníci v Brně. Bertramka. Věstnik Mozartovy obce v Československé Republice 2, 1950, Nr. 5-6, p. 1-3; 3, 1951, Nr. 2, p. 2-5; Nr. 5, p. 1-4.

ŠTEFAN, Jiří. Ecclesia metropolitana Pragensis catalogus collectionis operum artis musicae. Catalogus artis musicae in Bohemia et Moravia cultae, vol. IV. Praha 1983, 1985.

ŽU゚REK, Pavel. Questenbergovi hudebníci v Brně. I. díl. Opus musicum 42, 2010, Nr. 5, p. 50-64. 
